\title{
IDENTIFIKASI RISIKO PADA OKRA MENGGUNAKAN FAILURE MODE AND EFFECT ANALYSIS (FMEA) DI PT. MITRATANI DUA TUJUH DI KABUPATEN JEMBER
}

Risk Identification on Okra Product Using Failure Mode and Effect Analysis (FMEA) (A Case Study at PT. Mitratani Dua Tujuh, Jember Regency)

\author{
Ida Bagus Suryaningrat ${ }^{1) *}$, Wiwik Febriyanti ${ }^{1)}$, Winda Amilia ${ }^{1)}$ \\ ${ }^{1)}$ Program Studi Teknologi Industri Pertanian, Fakultas Teknologi Pertanian Universitas Jember \\ Jalan Kalimantan No. 37, Kampus Tegal Boto, Jember, Jawa Timur 68121 \\ *Korespondensi Penulis: suryaningrat.ftp@unej.ac.id
}

\begin{abstract}
Post-harvest is an activity processed from harvesting to becoming a product. Post-harvest handling aims to maintain the quality and minimize the loss of the agricultural product. Post-harvest loss of okra is the reduction of the okra harvest amount from picking up to transporting process. Many factors can cause the post-harvest loss of okra. This study aimed to determine the causal sources of the okra loss. This study used FMEA and fishbone diagram. Fishbone diagram was used to identify the causes of the okra loss in a fishbone skeleton. FMEA was used to give the value on the causes of the okra loss by assessing the severity, occurrence and detection to get the RPN value. The RPN value was used to rank the potential causes of the loss. From the result of the study, it was found that there were 4 main factors causing the okra loss which had the RPN value above the RPN critical value. It were lack of picker accuracy and training or counseling, handling pets and diseases, and age factor of picker.
\end{abstract}

Keywords: fishbone diagram, FMEA, okra, post-harvest loss

\section{PENDAHULUAN}

Pascapanen hasil pertanian merupakan kegiatan yang dilakukan mulai dari panen hingga pengolahan menjadi produk. Penanganan pascapanen bertujuan untuk menekan kehilangan hasil, meningkatkan kualitas, daya simpan, daya guna komoditas pertanian, memperluas kesempatan kerja, serta meningkatkan nilai tambah (Hasbi, 2012).

Tanaman okra merupakan salah satu jenis sayuran yang berasal dari benua Afrika. Budidaya Okra di Indonesia dimulai sejak tahun 1877. Kandungan gizi yang terdapat dalam okra sangat bermanfaat bagi kesehatan. Okra juga dimanfaatkan sebagai obat diabetes bagi penderita diabetes. Okra mengandung serat tinggi yang dapat membantu menstabilkan gula darah dengan mengatur tingkat gula yang diserap oleh tubuh melalui saluran usus (Gemede et al., 2014)
PT. Mitratani Dua Tujuh merupakan salah satu perusahaan yang bergerak pada budidaya dan pengolahan pangan. Salah satu tanaman yang dibudidaya adalah okra. Perusahaan tersebut mengolah okra menjadi produk okra frozen. Okra frozen dipasarkan secara lokal dan diekspor ke beberapa negara. Proses pemanenan okra di PT. Mitratani Dua Tujuh dilakukan secara manual menggunakan tenaga manusia. Pemanenan okra dapat dilakukan pada umur 50 sampai 110 hari. Penentuan umur panen dapat dilakukan secara visual dengan melihat kenampakan varietas (Nugraha, 2012).

Proses pemanenan hingga pascapanen menimbulkan risiko terjadinya kehilangan pascapanen. Pascapanen adalah serangkaian kegiatan yang meliputi pemanenan, pengolahan, sampai dengan hasil yang dikonsumsi. Kehilangan pascapanen (post-harvest loss) okra merupakan berkurangnya jumlah hasil 
panen okra mulai dari proses pemetikan, hingga pengangkutan. Kehilangan pascapanen okra disebabkan oleh beberapa faktor antara lain cara penanganan dan penggunaan alat (Ismawari, 2012). Risiko kehilangan pascapanen merupakan salah satu faktor yang dapat menyebabkan kerugian seperti berkurangnya jumlah hasil panen, khususnya bagi perusahaan. Risiko adalah probabilitas suatu kejadian yang mengakibatkan kerugian ketika kejadian itu terjadi selama periode tertentu (Badariah, 2016).

Perusahaan berupaya melakukan pengendalian risiko untuk menghindarkan kerugian. Langkah yang dilakukan untuk menekan kerugian kehilangan dengan melakakukan identifikasi risiko. Identifikasi risiko merupakan suatu cara yang dilakukan perusahaan dengan melakukan tindakan berupa mengidentifikasi setiap bentuk risiko yang dialami perusahaan, termasuk bentukbentuk risiko yang mungkin akan dialami oleh perusahaan. Identifikasi dilakukan dengan melihat potensi-potensi risiko yang sudah terlihat dan akan terlihat (Fahmi, 2011). Permasalahan yang menjadi pokok pembahasan dalam penelitian ini adalah kehilangan (loss) okra pada proses pascapanen. Kehilangan pascapanen bisa disebabkan oleh beberapa faktor diantaranya pengaruh cuaca, serangan hama dan penyakit, serta kurangnya ketelitian pemetik pada saat memetik tanaman okra sehingga menyebabkan tanaman okra tidak terpetik, terpotong dan terinjak-injak. Oleh karena itu untuk mengatasi beberapa permasalahan pascapanen di PT. Mitratani Dua Tujuh maka dilakukan identifikasi penyebab risiko dan mencegah permasalahan itu terjadi kembali.

Salah satu metode yang digunakan untuk mengidentifikasi sumber risiko loss okra adalah menggunakan metode diagram fishbone dan FMEA (failure mode and effect analysis). Diagram fishbone digunakan untuk mengidentifikasi faktor- faktor permasalahan yang berpengaruh secara signifikan terhadap output perusahaan. Diagram fishbone membantu perusahaan untuk mengetahui akar penyebab dari suatu permasalahan (Tanjong, 2013). FMEA digunakan untuk menganalisis serta memberi nilai rating bagi kegagalan yang sering terjadi (Salomon et al., 2015). Konsep FMEA adalah dilakukan penentuan rating keparahan, kejadian serta rating deteksi. Perhitungan RPN yang merupakan hasil kali ketiga rating tersebut menunjukkan tingkat risiko suatu kegagalan (Susetyo, 2009).

Berdasarkan permasalahan tersebut, untuk meminimalisir terjadinya kehilangan loss pada proses pascapanen okra, maka tujuan dari penelitian ini yaitu mengidentifikasi sumber-sumber risiko terjadinya kehilangan (loss) okra. Selain itu juga menganalisis dampak kehilangan okra mulai dari panen hingga pengangkutan dan memberikan rekomendasi terhadap sumber risiko prioritas kehilangan.

\section{METODE PENELITIAN}

\section{Alat dan Bahan}

Alat yang digunakan pada penelitian ini meliputi laptop dan microsoft office. Bahan yang digunakan dalam penelitian ini yaitu tanaman okra yang ada di lahan sampai proses pemanenan dan pengangkutan di PT. Mitratani Dua Tujuh di Kabupaten Jember.

\section{Tahapan Penelitian}

Penelitian ini dilaksanakan di lahan PT. Mitratani Dua Tujuh yang berlokasi di Desa Curahkates, Kecamatan Ajung, Kabupaten Jember pada bulan Januari hingga April 2018. Responden yang digunakan sebanyak 33 orang, terdiri dari pekerja petik, asisten manager dan manager area. Jumlah responden didapatkan dengan menggunakan perhitungan slovin dengan tingkat kepercayaan 90\%. Pengambilan sampel 
dilakukan dengan menggunakan metode purposive sampling. Kriteria penentuan responden yaitu dipilih berdasarkan pengalaman pekerja dengan syarat lama bekerja di PT. Mitratani Dua Tujuh, memiliki pengetahuan yang cukup tinggi mengenai proses pascapanen okra. Alat yang digunakan dalam penelitian ini adalah, microsoft exel, microsoft word, dan kuisioner. Bahan yang digunakan adalah tanaman okra mulai dari pemetikan hingga pengangkutan.

Penelitian pendahuluan dilakukan melalui wawancara serta survei langsung ke lokasi untuk mencari dampak dari kehilangan pada proses pascapanen. Setelah diperoleh informasi mengenai dampak terjadinya loss maka melakukan analisis loss menggunakan diagram fishbone. Diagram fishbone digunakan untuk merumuskan sebab akibat terjadinya kehilangan pascapanen okra mulai dari pemetikan hingga pengangkutan yang di gambarkan dalam sebuah kerangka tulang ikan. Selanjutnya dilakukan analisis dengan metode FMEA yang tujuannya untuk menentukan tingkat risiko dari setiap jenis kegagalan sehingga dapat diambil keputusan. Penentuan tingakt risiko menggunakan FMEA yaitu dengan melakukan penilaian tingkat severity, (dampaknya), occurance (kemungkinan munculnya kegagalan), dan detection (seberapa jauh dapat dideteksi). Pengumpulan data diperoleh melalui kuisioner yang telah dibagikan kepada responden. Risk Prioritas Number (RPN) merupakan hasil perkalian dari nilai severity, occurance dan detection $(\mathrm{RPN}=\mathrm{S}$ x O x D).

Setelah didapatkan nilai RPN dari masing-masing risiko, kemudian dilakukan perhitungan nilai kritis dari faktor-faktor risiko terjadinya kehilangan. Risiko yang memiliki nilai tertinggi kemudian dilakukan penanganan. Apabila ada 2 RPN yang sama, prioritas utama diberikan kepada item yang mempunyai nilai severity yang paling tinggi.

\section{HASIL DAN PEMBAHASAN}

Salah satu tools yang dapat membantu menganalisis penyebab terjadinya kehilangan okra adalah diagram fishbone. Penentuan kemungkinan penyebab kehilangan diangkat berdasarkan hasil diskusi dengan pihak-pihak terkait diantaranya manager, mandor, asisten manager serta berdasarkan hasil pengamatan lapang yang telah dilakukan sebelumnya. Kemungkinan terjadinya kehilangan okra terjadi pada tiga proses yaitu proses pemetikan, penimbangan serta pengangkutan.

Proses pemetikan merupakan salah satu tahapan terpenting dalam pascapanen okra sehingga kemungkinan penyebab kehilangan okra bisa terjadi pada proses ini. Pada proses pemetikan terdapat tiga faktor yang masing- masing faktor terdapat indikator yang menjadi penyebab terjadinya loss okra pada proses pascapanen yaitu lingkungan, manusia serta tanaman. Risiko diidentifikasi dari penyebab terjadinya peristiwa yang dapat menyebabkan loss pascapapen okra. Hubungan antara faktor manusia dengan proses pemetikan okra sangatlah penting. Hal itu dikarenakan pada proses pemetikan dilakukan secara manual oleh tenaga manusia, sehingga kemungkinan loss diakibatkan oleh manusia bisa terjadi. Faktor lingkungan memiliki indikator yang bisa berpengaruh terhadap penyebab kehilangan. 
Tabel 1.Sumber risiko terjadinya kehilangan pascapanen okra

\begin{tabular}{|c|c|c|c|c|}
\hline No. & Proses & Faktor & Sumber risiko & Efek kehilangan \\
\hline \multirow[t]{16}{*}{1.} & \multirow[t]{16}{*}{ Pemetikan } & \multirow[t]{4}{*}{ Lingkungan } & Curah hujan & Kualitas okra kurang baik \\
\hline & & & Bencana alam & Produktivitas okra menurun \\
\hline & & & Karakteristik tanah & Okra tejatuh, okra tidak terpetik \\
\hline & & & Pengairan atau draenase & Tanaman okra tidak tinggi \\
\hline & & \multirow[t]{8}{*}{ Manusia } & Kurang ketelitian & - Okra terpotong \\
\hline & & & pemetik & $\begin{array}{l}\text { - Okra tertinggal tidak terpanen } \\
\text { - Panjang okra }>12 \mathrm{~cm} \\
\text { - Okra tua }\end{array}$ \\
\hline & & & Pengalaman Pemetik & - Produktivitas rendah \\
\hline & & & & $\begin{array}{l}\text { - Okra yang terpetik tidak } \\
\text { sesuai standar }\end{array}$ \\
\hline & & & Kurangnya penyuluhan & Pengetahuan pemetik kurang \\
\hline & & & Faktor usia & - Okra tidak terpetik \\
\hline & & & & - Produktivitas berkurang \\
\hline & & & Pendidikan & Okra tidak sesuai standar mutu \\
\hline & & \multirow[t]{4}{*}{ Tanaman } & Hama dan penyakit & - Okra tidak sesuai standar \\
\hline & & & & - Okra bengkok > 90 \\
\hline & & & & - Bintil > 5 \\
\hline & & & $\begin{array}{l}\text { Penggunaan Pestisida } \\
\text { yang tidak tepat }\end{array}$ & Pertumbuhan okra tidak bagus \\
\hline \multirow[t]{5}{*}{2.} & \multirow[t]{5}{*}{ Penimbangan } & Alat & Kurang alat timbang & $\begin{array}{l}\text { Terburu-buru melakukan } \\
\text { penimbangan sehingga okra } \\
\text { terjatuh }\end{array}$ \\
\hline & & Lingkungan & $\begin{array}{l}\text { Lokasi timbang kurang } \\
\text { strategis }\end{array}$ & $\begin{array}{l}\text { Menyulitkan proses } \\
\text { penimbangan }\end{array}$ \\
\hline & & Manusia & Kurang pekerja timbang & Okra terjatuh \\
\hline & & & Kurang teliti & - Tercecer \\
\hline & & & & - Terinjak-injak \\
\hline \multirow[t]{4}{*}{3.} & \multirow[t]{4}{*}{ Pengangkutan } & Manusia & Penurunan okra yang & - Okra tercecer \\
\hline & & & kurang hati-hati dari pick & - Okra terjatuh \\
\hline & & & up & \\
\hline & & Lingkungan & $\begin{array}{l}\text { Jarak pengangkutan ke } \\
\text { perusahaan }\end{array}$ & Okra kegencet dan terjatuh \\
\hline
\end{tabular}

Penyebab terjadinya kehilangan pada proses penimbangan yaitu terdapat tiga faktor utama yang merupakan penyebab terjadinya kehilangan meliputi lingkungan, alat dan manusia. Faktor lingkungan sangat mempengaruhi terhadap kenyamanan pekerja. Apabila lokasi penimbangan yang digunakan strategis maka akan mempermudah pekerja dalam melakukan penimbangan. Berdasarkan faktor manusia, kehilangan (loss) okra disebabkan oleh manusia sangat memungkinkan terjadi, jika pada saat melakukan pemindahan okra ke bak-bak, para pekerja kurang hati-hati maka okra bisa terjatuh dan terinjak-injak.

Risiko kehilangan pada proses pengangkutan dipengaruhi oleh faktor lingkungan dan manusia. Kurangnya kehati-hatian dalam mengendarai pick up menuju pabrik menyebabkan okra tercecer. Terdapat 16 faktor risiko kehilangan pada pascapanen okra yang ditunjukkan pada Tabel 1. 


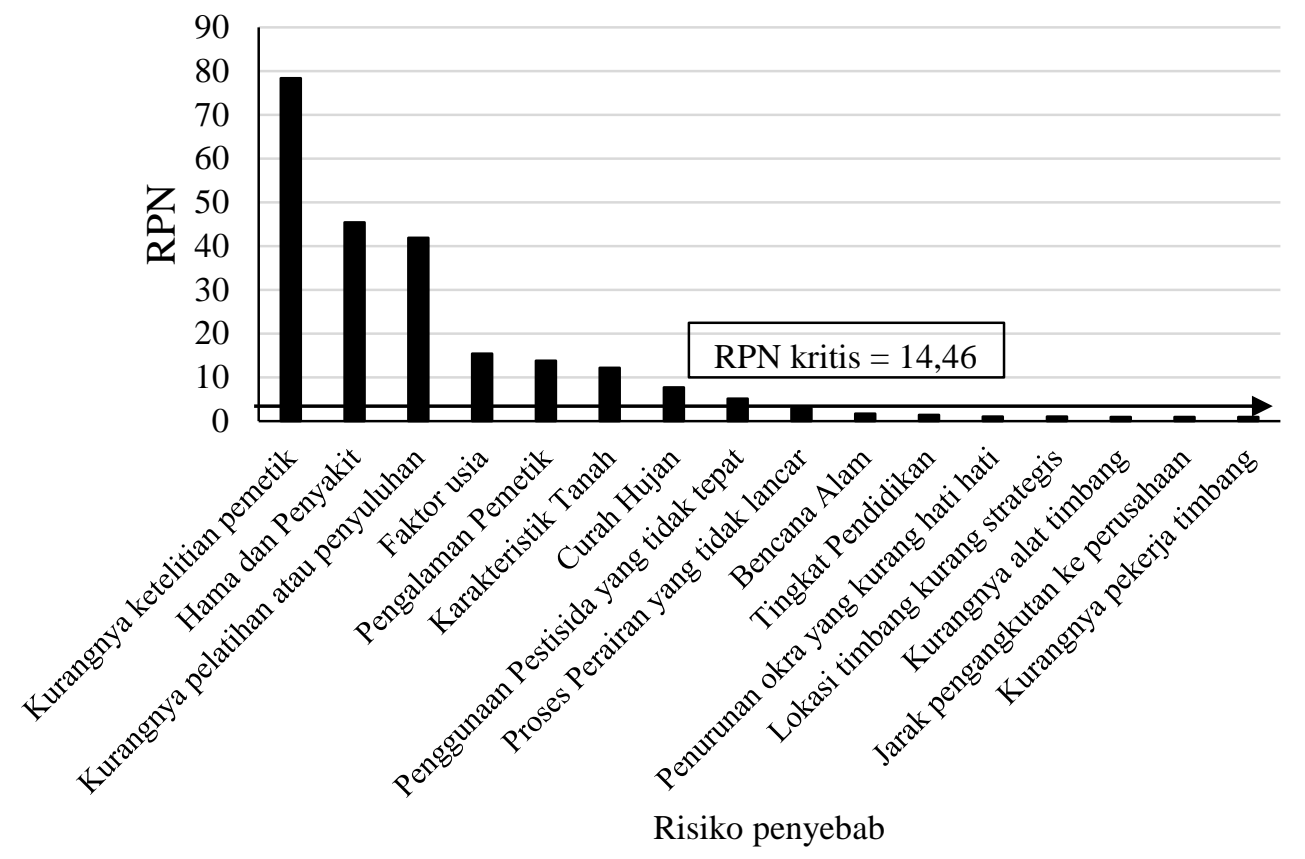

Gambar 1. Diagram penyebab loss okra

Berdasarkan Gambar 1 terdapat 16 risiko penyebab kehilangan okra diurutkan mulai dari risiko yang memiliki nilai RPN (risk prioritas number) terbesar hingga terkecil. Nilai kritis RPN pada okra adalah 14,46 , sehingga terdapat empat penyebab kehilangan (loss) okra yang memiliki nilai diatas nilai kritis dan menjadi prioritas penanganan.

Prioritas berdasarkan nilai RPN yang tertinggi. Apabila ada dua RPN sama maka prioritas utama diberikan kepada item yang memiliki nilai severity yang lebih tinggi. Perhatian lebih dilakukan apabila keseriusan dari efek kegagalan tinggi (severity). Selain itu, apabila nilai frekuensi tinggi maka akan berpengaruh terhadap biaya produksi. Hal tersebut dikarenakan banyak terjadi defect. Ketidakmampuan dalam mendeteksi kegagalan dapat berakibat pada ketidakpuasan konsumen (Hasbullah et al., 2017).
Tabel 2. Sumber risiko kehilangan kritis

\begin{tabular}{clcc}
\hline No. & Risiko & RPN & Rangking \\
\hline 1 & Kurangnya & 78,39 & 1 \\
& ketelitian pemetik & & \\
2. & Hama dan Penyakit & 45,41 & 2 \\
3. & Kurangnya & 41,91 & 3 \\
& pelatihan dan & & \\
& penyuluhan & & \\
4. & Faktor usia & 15,44 & 4 \\
\hline
\end{tabular}

Tabel 2 menunjukkan 4 risiko yang memiliki nilai RPN di atas nilai kritis. Kurangya ketelitian pemetik, hama penyakit, kurangnya pelatihan dan penyuluhan serta faktor usia. Kurangnya ketelitian pemetik bisa terjadi karena pemetik terburu-buru dalam melakukan pemetikan. Pemetik terburu-buru pada saat melakukan pemetikan karena mereka ingin segera berpindah dari satu petak kepetak yang lain agar tidak didahului oleh rekannya. Selain pada proses pemetikan, kurangnya ketelitian juga terjadi pada proses penimbangan, pemetik terburu-buru saat melakukan penimbangan sehingga 
terkadang okra terjatuh dan dan terinjakinjak.

Berdasarkan Tabel 1 dengan menggunakan metode FMEA, nilai RPN hama dan penyakit adalah 45,41 . Hama dan penyakit merupakan salah satu faktor penyebab terjadinya loss pascapanen okra. Hama dan penyakit okra antara lain ulat, dan wereng. Loss okra karena hama dan penyakit dapat terjadi karena pada saat melakukan penyemprotan kurang tepat sasaran, misalnya penyemprotan yang seharusnya dilakukan pada bagian bawah daun, namun yang disemprot di atas daun. Hal tersebut menyebabkan penyakit yang berada di bawah daun tidak mati.

Nilai RPN yang menempati rangking ketiga adalah kurangnya pelatihan dan penyuluhan. Nilai RPN kurangnya pelatihan dan penyuluhan adalah 41,91. Kurangnya pelatihan atau penyuluhan sanagt berpengaruh terhadap kehilangan okra, misalnya okra yang dipetik minimal ukuran $6 \mathrm{~cm}$ namun ternyata yang dipetik kurang dari $6 \mathrm{~cm}$. pelatihan terhadap pemetik sangat diperlukan untuk meningkatkan produktivitas pekerja serta wawasan pemetik pada saat bekerja. Dengan diadakannya pelatihan maka dapat berpengaruh positif signifikan terhadap produktivitas kerja karyawan (Syahrul dan Sari, 2016).

Penyebab loss yang menempati rangking keempat adalah faktor usia dengan nilai RPN 15,44. Faktor usia merupakan salah satu penyebab terjadinya loss okra. Semakin bertambahnya usia pekerja maka tingkat ketelitian semakin bekurang sehingga berdampak pada tidak terpetiknya okra atau ketinggalan, kemudian hasil panen yang kurang maksimal. Usia merupakan salah satu faktor yang mempengaruhi produktivitas tenaga kerja. Bertambahnya usia, maka produktivitas menurun. Penurunan ini dapat disebabkan oleh kondisi fisik dan kesehatan yang semakin melemah (Pratama dan Andriani, 2015).

\section{Rekomendasi Perbaikan \\ Kurangnya Ketelitian}

Rekomendasi untuk kurangnya ketelitian pemetik adalah dalam satu area dengan luas lahan 5 Ha maka pekerja petik dibagi menjadi 2 kelompok. 1 kelompok pemetik terdiri dari 20 hingga 30 orang pemetik dan 1 ketua kelompok, sehingga dalam satu area terdapat sekitar 40 sampai 50 pemetik dan 2 ketua kelompok. Pembagian luas area menjadi dua kelompok pekerja bertujuan untuk memotivasi pemetik dalam melakukan pemetikan. Jika dalam satu area terdapat dua kelompok, maka akan meningkatkan rasa bersaing antar kelompok, sehingga para pemetik lebih semangat untuk memetik okra dan mereka akan bersaing untuk memperbanyak jumlah produksi di masing-masing kelompok. Selain membagi menjadi 2 kelompok dalam satu area, rekomendasi usulan untuk meningkatkan ketelitian pemetik yaitu dengan melakukan controlling setiap hari, controlling bisa dilakukan oleh asisten manager dan oleh pekerja lokal. Controling bisa dilakukan dengan pengawasan yang ketat oleh asisten manager serta melakukan sidak dua minggu sekali. Sidak dilakukan pada pemetik, penyemprot tanaman, pekerja timbang, serta proses pengangkutan yang bertujuan untuk memperketat pengawasan serta meminimalisir kehilangan pascapanen okra.

\section{Rekomendasi Hama dan Penyakit}

Rekomendasi perbaikan untuk penanganan hama dan penyakit yaitu diperlukan pengawasan yang maksimal serta pengetahuan pekerja tentang hama penyakit sehingga pekerja cepat tanggap dalam menangani hama dan penyakit. Selain itu melakukan sanitasi lahan dengan mengambil buah yang terserang hama dan penyakit kemudian dibuang. Perbaikan untuk penanganan hama dan penyakit yaitu dengan membagi 2 petak untuk penyemprotan. Selama ini penyemprotan dibagi menjadi 3 petak, sehingga kurang 
efisien. Hal tersebut dikarenakan jika dibagi menjadi 3 petak maka penyemprotan akan selesai dalam waktu 3 hari. 1 hari untuk istirahat sehingga penyemprotan kembali dilakukan pada hari ke 5. Hal itu menyebabkan hama dan penyakit menyerang tanaman okra, jika waktu penyemprotan lama.

\section{Kurangnya Pelatihan atau Penyuluhan}

Rekomendasi kurangnya pelatihan atau penyuluhan adalah perlu dilakukan briefing setiap hari sebelum pekerja di lahan memulai aktivitas mereka. Briefing dilakukan berkaitan dengan bagaimana cara pemetikan yang benar, ukuran okra yang harus dipetik, penyemprotan tanaman okra yang benar, perawatan okra, dan pemberian pupuk pada okra. Selain briefing juga dapat dilakukan pelatihanpelatihan dari pihak perusahaan kepada pekerja. Pelatihan-pelatihan yang diberikan tujuannya untuk menambah wawasan pekerja. Seperti pada perusahaan makanan dan sparepart (Badariah et al., 2016 dan Tanjong, 2013), perusahaan tersebut selalu melakukan briefing sebelum mereka memulai bekerja. Selain itu perusahaan tersebut juga memberikan pelatihan-pelatihan yang berkaitan dengan pekerjaannya setiap dua minggu sekali secara bergantian kepada semua pekerja dan karyawan. Selanjutnya pengontrolan oleh pihak asisten manager dilakukan untuk mengetahui hasil atau dampak dari diadakannya briefing dan pelatihan. Pengontrolan bisa dilakukan dengan melakukan sidak. Sidak dilakukan minimal dua minggu sekali.

Dengan dilakukan pengontrolan, asisten manager bisa mengetahui dampak dari diadakannya briefing dan pelatihan. Apabila berdampak baik maka hal itu perlu diterapkan serta ditingkatkan. Motivasi juga diperlukan oleh pekerja petik okra untuk menumbuhkan semangat pemetik.
Tindakan motivasi yang dapat diberikan adalah dengan membuat kelompok gugus mutu. Gugus mutu merupakan suatu kelompok, terdiri dari 410 orang yang mengerjakan pekerjaan yang sama dan bertujuan untuk meningkatkan kemampuan serta kualitas pekerja baik dalam bekerjasama, berkomunikasi maupun dalam meningkatkan kreativitas (JUSE, 1991). Peranan gugus kendali mutu (GKM) terhadap produktivitas kerja karyawan pada Usaha Tenun Songket Winda Pekanbaru sudah diterapkan dan berjalan baik. Akan tetapi perlu peningkatkan produktivitas karyawan agar memenuhi standar perusahaan melalui memperhatikan kondisi fisik pekerjaan dan meningkatkan kecakapan kerja karyawan melalui pelatihan atau penyuluhan sesuai dengan bidang kerjanya (Nuryanti, 2014). Di sisi lain, sebaiknya perusahaan menerapkan gugus kendali mutu sesuai dengan pedoman GKM yang benar dan sesuai dengan kondisi perusahaan (Ravianto, 2004).

\section{Faktor Usia}

Usia tenaga kerja cukup menentukan keberhasilan dalam melakukan suatu pekerjaan. Umumnya tenaga kerja yang berumur tua memiliki tenaga fisik yang lemah dan terbatas, sebaliknya tenaga kerja dengan umur masih muda memiliki kemampuan fisik yang kuat (Amron dan Imran, 2009).

Rekomendasi perbaikan untuk faktor usia adalah perlu adanya kriteria usia yang ditetapkan oleh PT. Mitratani Dua Tujuh saat merekrut pekerja petik baru. Hal ini sangat diperlukan karena usia akan berpengaruh terhadap produktivitas yang dilakukan. Kriteria yang perlu ditentukan seperti usia pekerja maksimal berusia 55 tahun. Dibuat pemetaan dengan membagi pekerja berdasarkan usia. Pekerja yang usianya tua diberi lokasi pemetikan yang medannya tidak sulit. 


\section{KESIMPULAN}

Aplikasi metode FMEA pada pascapanen okra di PT Mitratani Dua Tujuh menghasilkan 4 indikator yang memiliki nilai RPN di atas nilai RPN kritis, meliputi kurangnya ketelitian pemetik, hama dan penyakit, kurangnya pelatihan atau penyuluhan dan faktor usia. Tindakan perbaikan untuk meminimalisir terjadinya loss okra pada proses pascapanen meliputi, pembagian area pemetikan yang dibagi menjadi 2 petak. Dalam satu area terdapat 2 kelompok pemetik dan dilakukan rolling setiap hari. Penyemprotan hama dan penyakit dibagi menjadi 2 kelompok tanpa di rolling dan penyemprotan diselesaikan dalam dua hari. Penambahan wawasan pekerja dilakukan dengan melakukan pelatihan dan melakukan controlling untuk semua proses dengan mengadakan sidak 2 minggu sekali.

\section{DAFTAR PUSTAKA}

Amron dan Imran, T. 2009. Analisis faktorfaktor yang berpengaruh terhadap produktivitas tenaga kerja pada outlet telekomunikasi seluler Kota Makasar Jurnal Sekolah Tinggi Ilmu Ekonomi Nobel Indonesia.

Badariah, N., Surjasa, D., dan Trinugraha, Y. 2016. Analisis supply chain risk management berdasarkan metode failure mode and effects analysis (FMEA). Jurnal Teknik Industri, 2 (2): 110-118

Fahmi, I. 2011. Manajemen Risiko. Alfabeta, Bandung.

Gemede, H.F., Ratta, N., Haki, G.D., Woldegiorgis, A.Z., and Bey, F. 2014. Nutritional quality and health benefits of okra (Abelmoschus esculentus): A review. Global Journal of Medical Research, 14 (5): 29-37.

Hasbi. 2012. The improvement of rice postharvest technology in sub-optimal land. Jurnal Lahan Suboptimal, 1 (2): 186-196.
Hasbullah, H., Kholil, M., dan Santoso, D.W. 2017. Analisis kegagalan proses insulasi automotive wires (AW) dengan metode failure mode and effect analysis (FMEA). SINERGI, 21 (3): 197-199.

Ismawari, K. 2012. Kesiapan teknologi panen dan pascapanen padi dalam menekan kehilangan hasil dan meningkatkan mutu beras. Jurnal Litbang Pertanian, 31 (2): 58-59.

Japanese Union of Scientists and Engineers (JUSE). 1991. Gugus Kendali Mutu. Cetakan ketiga. Diterjemahkan (editor) oleh Rochmulyati Hamzah. PT Pustaka Binaman Pressindo, Jakarta.

Nugraha, S. 2012. Inovasi teknologi pascapanen untuk mengurangi susut hasil dan mempertahankan mutu gabah/beras di tingkat petani. Buletin Teknologi Pascapanen Pertanian, 8 (1): 51-52.

Nuryanti. 2014. Peranan gugus kendali mutu terhadap produktivitas kerja karyawan (studi kasus pada Usaha Tenun Songket Winda Pekanbaru). Jurnal ekonomi, 22 (2): 138-150.

Pratama, R.A., Andriani, R.D. 2015. Analisis faktor-faktor yang mempengaruhi produktivitas kerja pemetik teh di PTPN XII (Persero) Kebun Wonosari. Habitat, 26 (1): 1-9.

Ravianto, J. 2004. Manajemen Produksi dan Produktivitas. Penerbit Bina Pustaka Idaman, Jakarta.

Salomon, L., Ahmad, L., dan Limanjaya, D.N. 2015. Strategi peningkatan mutu part bening menggunakan pendekatan motede six sigma studi kasus Departemen Injection di PT. KG. Jurnal Ilmiah Teknik Industri, 3 (3): 156-165.

Susetyo, J. 2009. Analisis pengendalian kualitas dan efektivitas dengan integrasi konsep failure mode and effect analysis dan fault tree analysis serta overall equipment effectiveness. Jurnal Teknologi Technoscientia, 2 (1): 70-77. 
Syahrul, R.A., dan Sari, R.A. 2016. Analisis disiplin kerja dan pelatihan terhadap produktivitas kerja karyawan pada Kantor BPJS Ketenagakerjaan Padang. Journal of Economic and Economic Education, 5 (1): 25-38.

Tanjong, D.S. 2013. Implementasi pengendalian kualitas dengan metode statistik pada pabrik spareparts CV Victory Metallurgy Sidoarjo. Jurnal Ilmiah Mahasiswa Universitas Surabaya, 2 (1): 1-6. 